\title{
Türk-Hırvat Teknik Şartnamelerinin Yol Altyapısı Açısından Karşılaştırılması
}

\author{
Onur ŞAHINKAYA ${ }^{1}$, Onur ÖZTÜRK*², Erkan BOZKURTOĞLU ${ }^{3}$
}

İTÜ FBE, 34469, Ayazağa, İstanbul/ TÜRKIYY, onursahinkaya@gmail.com

İTÜ FBE, Jeoloji Mühendisliği, 34469, Ayazağa, İstanbul/ TÜRKIYE, onur.ozturk@live.com Jeoloji Mühendisliği , 34469, Ayazağa, İstanbul/ TÜRKIYE, erkanbozkurtoglu@gmail.com

Received/Geliş: 30.03.2018 Revised/Düzeltme: 02.05.2018 Accepted/Kabul: 02.05 .2018

Öz: Teknik şartnameler, projelerin istenilen kalitede ve sürede gerçekleştirilebilmesi için uygulanması gereken kuralları tanımlayan açıklamalardır. Bir işin yapılabilmesi için gerekli bütün bilgilerin teknik şartnamelerde tam ve eksiksiz biçimde tanımlanması gerekir. İmalata ait işçilik, malzeme, ekipman ve kalite kontrol koşulları şartnamelerde tam olarak açıklanmalıdır. Bu çalışmada Türkiye'de karayolları yapımında teknik şartname olarak kullanılan Karayolları Teknik Şartnamesi (KTŞ) ile son dönemde Balkanlar'da yapılan karayollarında kullanılan Hırvat Teknik Şartnamesi (HTŞ), yol altyapısı açısından, kazı ve dolgu işleri temel alınarak karşılaş̧ırılmıştır. Çalışmada her iki şartnamede geçen malzeme tanımları, iş yapım metodları ve kalite kontrol süreçleri ele alınmış, yapım sonrasında imalatın kalitesinin korunması için yapılması gereken testler açıklanmış ve sıklıkları karşılaştırılmıştır. Çalışmanın sonucunda, her iki şartnamenin birbiriyle olan benzerlikleri ve farklılıkları yorumlanarak öneriler sunulmuş ve teknik şartname seçiminin önemi vurgulanmıştır.

Anahtar kelimeler: Yol altyapısı, teknik şartnameler, karayolları teknik şartnamesi.

\section{A Comparison of Turkey and Croatian Technical Specifications for Road Infrastructure}

\begin{abstract}
Technical specifications are descriptions of which provide required documentation during projects exection in order to obtain quality. It is important that technical specification is accurate and complete, because it should contain all necessary information to work done properly. Labor, material, equipment and quality control requirements should be described fully in specifications. In this study, Highways Technical Specification that are used in construction of highways in Turkey with Croatian Technical Specification that are recently used in highways construction at Balkans are compared in terms of earthworks and quality control requirements. Material requirements and descriptions, construction methods and quality control processes of both technical specifications are covered and compared in detail. In conclusion, aspects of similarities and differences in both specifications are evaluated.
\end{abstract}

Key words: Road infrastructure, technical specifications, highways technical specification.

\section{Giriş}

Teknik şartnameler, projelerde tamamlananacak imalatların gerçekleştirilebilmesini sağlayan yazılı dökümanlardır. Bir işin yapılabilmesi için gerekli bütün bilgiler teknik şartnamelerde olması gerektiğinden şartnamelerin eksiksiz ve açık bir dilde yazılmış olması gerekir. Şartnamelerde imalata ait işçilik, malzeme, ekipman ve kalite kontrol koşulları tam olarak açıklanmalıdır. Şartnamelerin incelenmesi, bir projenin teklif aşamasından tamamlanma aşamasına kadar büyük önem

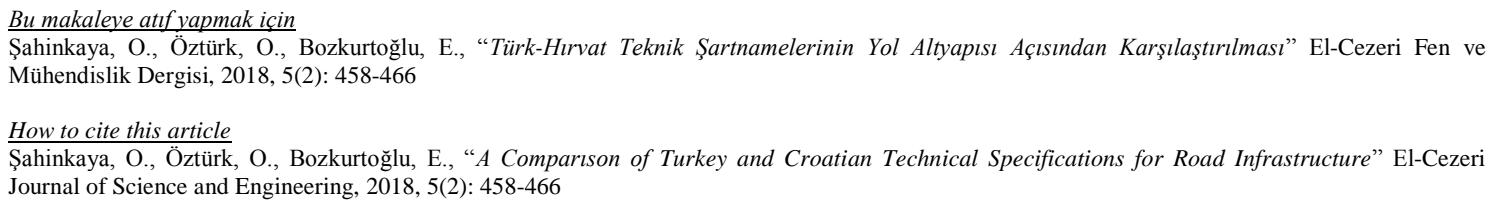


taşımaktadır. Şartnamelerin içerdiği limitlere göre, proje için temin edilecek her türlü malzeme ve ekipman gereksinimleri değişebilmektedir. Bu sebeplerden teknik şartnameler maliyet açısından proje sürecini etkileyen önemli kalemlerdendir. $[1,2]$

Hırvatistan, Yugoslavya'nın dağılması sonrasındaki süreçte bölgede kurulan devletler içerisinde en fazla yol yapımı planan ve gerçekleştirilen ülke olmuştur. Bu nedenle, Yugoslav standartlarının güncellenmesi ihtiyacı doğmuş, 2001 yılında Hırvat Teknik Şartnamesi yayımlanmıştır.

Daha önceki şartname karşılaştırma çalışmaları; Esnek Üstyap1 Tasarım Yöntemlerinin Karşılaştırması, Esnek Üstyapıların Projelendirilmesinde AASHTO 1972 ve AASHTO 1986 Yöntemlerinin Karşılaştııılması, Esnek Üstyapı Tasarım Yöntemlerinden AASHTO 2002 ile AASHTO 1993 Yönteminin Karşılaştırması üzerine yapılmıştır [3-6]. Bu çalışmanın temel farkı, karayolu altyapısını oluşturan kazı, dolgu ve sıkıştırma işlemlerini malzeme özellikleri, yapım metodları ve kalite gereksinimleri açısından karşılaştırmaktır. Kullanılan her iki şartname de yayınlandığı tarih itibariyle yeni kabul edilebilecek şartnameler olduğundan, iki şartname arasında daha önce bir karşılaştırma yapılmamıştır.

Hırvat Teknik Şartnamesi ile karşılaştırılan Karayolları Teknik Şartnamesi ise 2006 yılında uluslararası standartlara ve son teknolojik gelişmeler esas alınarak yeniden düzenlenerek Karayolları Genel Müdürlüğü, Merkez ve Bölge Teşkilatlarınca yapılacak işlerde uygulamaya konulmuştur. Türkiye'de teknik şartname özellikleri:

-Türkiye'de teknik şartname yazımına ilişkin çalışmalar yapan herhangi bir özel kuruluş bulunmamaktadir.

-Kamu kurumlarında yapılan şartnamelerde bayındırlık işleri teknik şartnamesi, karayollarında yapılan işlerde karayolları teknik şartnamesi, bunlara ek olarak elektrik tesisatı genel teknik şartnamesi, makine genel teknik şartnamesi ve ödemelere esas teşkil eden birim fiyat tarifleri kullanılmaktadır.

-Türk Standartları Enstitüsü (TSE) tarafindan hazırlanan inşaat sektörüyle ilgili standartlar bulunmakta, çoğunlukla inşaat malzemelerinin fiziksel ve kimyasal özelliklerinden oluşmaktadır.

Hırvatistan Teknik Şartnamesi (General Technical Requirements, GTR), yol projelerindeki bireysel birçok işin teknik olarak yapım metodlarını ve standartlarını içerir. Teknik şartnamenin ilk baskısı 1976 yılında o zamanki Yugoslavya içerisinde, ikinci baskısı 1989 yılında yayımlanmıştır. Bu şartname, Yugoslavya'nın bölünmesinden sonra ilk olarak bağımsızlığını kazanan ve şu ana dek en fazla karayolu inşaatı gerçekleştirilen ülke olan Hırvatistan'da ve Arnavutluk, Kosova gibi diğer Balkan ülkelerindeki otoyolların yapımında teknik şartname olarak kullanılmaktadır. 2006 yılı Karayolları Teknik Şartnamesi (KTŞ) ile karşılaştırılan Hırvat Teknik Şartnamesi ise 2001 yılında yayınlanmıştır. Hırvat Teknik Şartnamesi (GTR), Hırvatistan İnşaat Mühendisliği Enstitüsü [Institut Graðevinarstva Hrvatske (IGH)] tarafından hazırlanmıştır. Yayınlanan bu şartname 6 ana kısımdan oluşmaktadır.

\section{Türk ve Hırvat teknik şartnamelerinin karşılaştırılmasıı}

\subsection{Hırvat Teknik Şartnamesi ve Karayolları Teknik Şartnamesinde (KTŞ) Kazı Iş̧leri}

Hırvat Teknik Şartnamesinde (HTŞ), kazı işleri ile ilgili şartname detaylarına öncelikle toprak işleri ile ilgili tanımların; geotekstil, geokompozitler, geogridler, palye vb. tanımların verilmesi ile giriş yapılmıştır. Karayolları Teknik Şartnamesinde ise bu ve karayolları ile ilgili tüm tanımlar giriş bölümünde verilmiş, ayrıca bölüm içerisinde yer verilmemiş̧ir [7].

Hırvat Teknik Şartnamesinde kazı işleri ilk olarak yüzeyde bulunan nebati toprak kazısı özelinde açıklanmıştır. Nebati toprak, $10 \%$ dan fazla organik madde içermeyen, doğal zemin üzerinde kalınlığı kontrol mühendisi tarafından belirlenecek toprak tabakası olarak tanımlanmıştır.

Karayolları Teknik Şartnamesinde ise nebati, bitkisel toprak kazısı ile ilgili Hırvat Şartnamesindeki kadar işin yapımına ait detaylı açıklamalar bulunmayıp, bitkisel toprağın kontrol mühendisnin uygun gördüğü kazı ve ariyet ocaklarından alınıp, şevlerin bitkisel toprak teşkilinde kullanılmak üzere uygun yerde depo edilmesi gerektiği belirtilmiştir.

Hırvat Teknik Şartnamesinde (HTŞ) kazı işleri, HTŞ ikinci bölümde, plan ve projelerdeki kot ve eğimlere uygunlukta, yarmaların, hendeklerin, her türlü yol düzenleme işindeki kazı işlerinin yapılması ve uygun nitelikteki araçlara malzemenin yüklenmesi olarak tanımlanmıştır. 
Kazı işlerinin; ön yüzden bütün alanın kazılması, yarmaların tek taraflı olarak kazılması veya yatay katmanlar biçimde kazıların yapılması metodlarından birinin ya da birden fazlasının seçilmesiyle yapılabileceği belirtilmiştir.

Hırvat Teknik Şartnamesinde kazı işlerindeki zemin tipleri üç ana başlığa ayrılmıştır:

-A tip malzeme

-B tipi malzeme

$-\mathrm{C}$ tipi malzeme

A tip malzeme; bütün işin yapımında patlatma operasyonlarının gerekli olduğu, patlatmadan çıkan malzeme olarak tanımlanmıştır. Bu tip malzeme, her türlü kaya, metamorfik ve sedimantel oluşmuş kayaçlar, yerel tabakalar halindeki çok sert killer olabilir. Bir başka deyişle, KTŞ'de çok sert kaya kazısı ile ifade edilen zemin tipinin Hırvat Teknik Şartnamesindeki karşılığıdır.

B tipi malzeme; kazı işlerinin bir kısmının gerekli ekipman,bir kısmının patlatma ile gerçekleştirileceği, gevşek malzemeler ile, homojen marn, kum kil karışımları, birçok dolomitler, yerel parçalanmış kayalar, kireçtaşı, her çeşit şist ve birçok konglemera tipi malzeme kazısı bu sınıf içerisinde değerlendirilmiştir.

HTŞ'de, B sınıfı malzeme olarak sınıflandırılan malzeme, Karayolları Teknik Şartnamesinde sert kaya kazısı ile sınıflandırılan başlık ile örtüşmektedir.

C tip malzeme, kazı yapılması için patlatma operasyonlarının gerekli olmadı̆̆ı, el veya uygun ekipmanlar; ekskavatör, dozer vb. yardımıyla gerçekleştirilebilecek her tip kazıdan çıkan malzeme olarak sınıflandırılmıştır. C sınıfı malzeme; kil, silt, siltli kil , ince taneli sıkı zeminler, kum çakıl veya bunların parçaları, iri taneli kohezyonsuz zeminlerden oluşan malzemeler olarak tanımlanmıştır.

HTŞ'de C sınıfı malzeme olarak sınıflandırılan malzeme, Karayolları Teknik Şartnamesinde yumuşak kaya kazısı ile sınıflandırılan malzeme tipine karşılık gelmektedir.

$\mathrm{Bu}$ ön tanımlardan sonra, Hırvat Teknik Şartnamesinde A, B, C sınıfı kazı yapımı daha da detaylandırılmıştır. A sınıfı geniş kazı yapımı olarak isimlendirilen bölümde A sınıfı kazı yapım aşamaları;

- Her türlü patlayıcı kullanımından önce, gerekli yasal gereksinimlerin yerine getirilmesi, yolun güvenliğinin sağlanması,

- Patlatma sonrasında minimum seviyede kırma işinin çıkması için kontrol mühendisinin onayıyla ön çatlatma metodunun uygulanması,

- Patlatılmış malzemenin ve kazının alttemel seviyesine kadar tamamlanıp zaman geçirilmeden drenaj işlemlerinin gerçekleștirilmesi,

- Patlatılmış malzemenin taşıma araçlarına yüklenerek depo veya dolgu alanlarına taşınması olarak açıklanmıştır.

HTŞ'de, B ve C sınıfı kazı yapım işlemleri de benzer şekilde detaylı olarak açıklanmış, karayolları teknik şartnamesinde kazı işlerinden önceki ve sonraki bölümlerde açıklanan; ariyet ocaklarının seçimi öncesinde kontrolün onayı, taşıma diyagramının kontrol mühendisine sunulması ve onayının alınması, ariyet ocaklarının öngörülenden fazla kullanımı için işveren onayı istenmesi, kazı işlerinde meydana gelecek her hürlü yıkım ve zararın maliyetinin yükleniciye ait olduğu bu açıklamalar içerisinde belirtilmiştir.

Kazılan miktarların hesaplanması detaylandırılan bu kısımlar baz alınarak; enkesitler ve yerindeki hacimler üzerinden hesaplanacak, kontrol mühendisi tarafından kazılan hacmin ne kadarının A, B ve C sınıflarına ait olduğu belirli yüzdelerle belirlenecek, daha sonra sözleşmede belirtilen sınıflara ait birim fiyatlar üzerinden ödeme yapılacaktır. Kazı birim fiyatına tüm kazı işlemleri, kazılan malzemenin uygun araçlara yüklenmesi, kazılan bölgenin nebati serimine uygun hale getirilmesi için yapılacak diğer bütün işlemler dahil edilmiştir.

HTŞ'de kazı işleri, A, B, C sınıfı kazı işlerinin detaylandırılmasından sonra; hendek kazılarının yapılması, palye kazılarının yapılması, temel kazılarının yapılması, hendek ve kanal kazılarının yapılması, malzemenin taşınması gibi diğer başlıklar ile açıklanmıştır.

HTŞ'de palye kazılarının, \%5 eğimi aşmayacak şekilde $2 \mathrm{~m}$ ila $5 \mathrm{~m}$ arasında yapılması gerektiği, zeminin kendini tutabildiği yerlerde yapımına gerek olmadığı açıklanmıştır.

KTŞ'de palye yapımı, kısım 313 drenaj işleri bölümünde incelenmiştir. Drenaj hendekleri olarak ele alınan bu kısım Hırvat teknik şartnamesindeki incelemenin aksine, dolgu ve yarma şevlerindeki palyeler olarak iki ana bölüme ayrılmış, ilgili çizimlerle detaylı olarak açıklanmıştır. Dolgu 
şevlerinde palye genişliği 10 metreden yüksek dolgularda minumum 5 metre olarak \%5 eğimle teşkil edileceği belirlenmiștir.

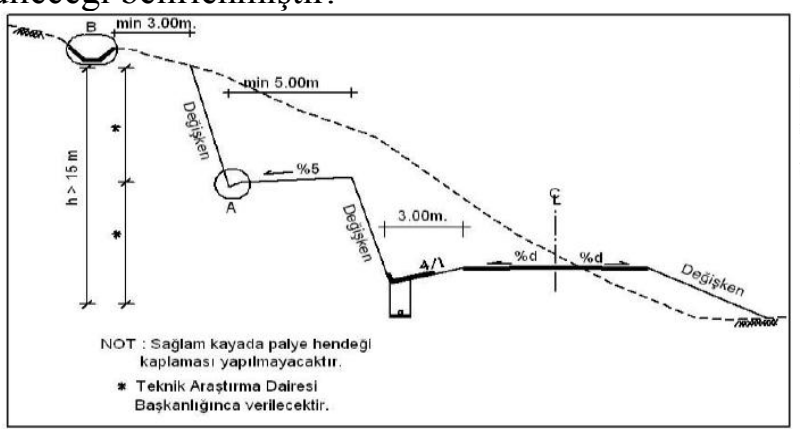

Şekil 1. Palyeli yarma enkesit tipi

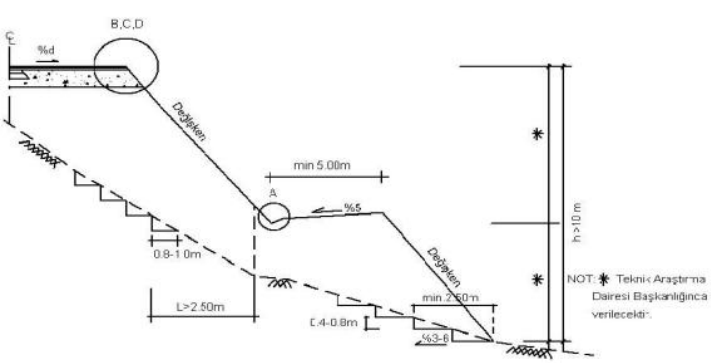

Şekil 2. Palyeli dolgu enkesit tipi

Her iki şartnamedeki kazı sınıfları ve bunların birbiriyle eşleştirilmesi Tablo 1'de verilmiştir [7-8].

Tablo 1. KTŞ ve HTŞ kazı sınıfları karșılaștırması.

\begin{tabular}{|l|l|}
\hline Karayolları Teknik Şartnamesi & Hırvat Teknik Şartnamesi \\
\hline Çok sert kaya kazısı & A sınıfı kazı \\
\hline Yumuşak kaya-sert kaya kazısı & B sınıfı kazı \\
\hline Genel Kazı (kil,kum,çakı1) & C sınıfı kazı \\
\hline
\end{tabular}

KTŞ'de yol kazısı bölümünde, şevlerin kazısında kayalık zeminlerde $\pm 10 \mathrm{~cm}$, toprak zeminlerde \pm 5 cm'lik farkların kabul edilebilir olduğu belirtilmiştir. Ayrıca, güzergahta imalat kotları ile proje kotları arasında $\pm 5 \mathrm{~cm}$ 'lik kot farkının kabul edilebilir olduğu belirtilmiştir. HTŞ'de ise sahadaki imalatın proje verilerine göre yapılacağı belirtilmiş olup herhangi bir fark tolere edilmemiştir. KTŞ'de izin verilen bu toleranslar, idare açısından olumsuz durumlara yol açabilir. Uzun mesafelerde, izin verilen farklar dahilinde yapılan kazı imalatı hataları yüklenicinin projede öngörülenden fazla miktarda para almasına imkan tanımaktadır. KTŞ'de ve HTŞ'deki taşımalar ve buna ait ödemeler incelendiğinde, KTŞ'de taşıma işleri tesviye işlerinde taşımalar ve ayrıca ödenecek taşımalar olmak üzere iki başlıkta incelenmiştir. HTŞ'de ise yalnızca tesviye işlerinde taşımalar kısmı mevcuttur. Bu karşılaştırma Tablo 2'de gösterilmiştir.

Tablo 2. KTŞ ve HTŞ taşıma sınıfları karşılaştırması

\begin{tabular}{|l|l|l|}
\hline Taşıma türü & KTŞ & HTŞ \\
\hline Tesviye işlerinde taşımalar & Var & Var \\
\hline Ayrıca ödenecek taşımalar & Var & Yok \\
\hline
\end{tabular}

KTŞ'de tesviye işlerinde taşımalarda ödemeye esas taşıma mesafesi, malzemenin yerindeki ağırlık merkezi ile taşımadan sonra bununla inşa edilecek kısmın ağırlık merkezleri arasındaki yatay mesafedir. HTŞ'de ise böyle bir hesap yöntemi bulunmamakta, taşıma mesafeleri 5 km'e kadar olan taşımalar ve $5 \mathrm{~km}$ 'den fazla olan taşımalar olarak gruplandırılmaktadır. Her iki şartnamede benzer şekilde, ariyet ocağı taşımalarında taşıma mesafesinin kütleler diyagramından hesap edilmeyip idare tarafından belirlenen yolun mesafesinin ölçümü sonucunda tespit edileceği belirtilmiştir.

KTŞ ve HTŞ'deki dolgu malzemelerinin sağlaması gereken koşulların karşılaştırması Tablo 3'de verilmiştir. Tabloya göre KTŞ su muhtevası daha yüksek zeminlerin dolguda kullanılmasına imkan tanımaktadır. Malzemeler en fazla KTŞ'ye göre \%3, HTŞ'ye göre $\% 4$ oranında şişme göstermelidir. Fazla şişme gözlenen durumlarda malzemelerin kullanılabilirliği ek araştırma raporuna göre belirlenir. 
Tablo 3. KTȘ ve HTȘ dolgu malzemesi karşılaștırması

\begin{tabular}{|l|l|l|}
\hline Deney & KTŞ & HTŞ \\
\hline Likit Limit (LL), $\%$ & $<60$ & $<65$ \\
\hline Plastisite İndeksi (PI),\% & $\leq 35$ & $\leq 30$ \\
\hline $\begin{array}{l}\text { Maksimum kuru birim ağırlık } \\
\text { (Standard Proctor) }\end{array}$ & $\geq 1.45 \mathrm{tn} / \mathrm{m}^{3}$ & $\geq 1.50 \mathrm{tn} / \mathrm{m}^{3}$ \\
\hline
\end{tabular}

KTŞ ve HTŞ'de, dolguların üstyapı tabanında kullanılacak malzemelerin sağlaması gereken koşullar Tablo 4'de karşılaştırılmıştır. Tabloya göre HTŞ'de dolguların yapımında kullanılacak zeminlerin özellikleri, KTŞ’ye göre dolguda kullanılabilecek zeminlerin özelliklerine göre daha iyidir.

Tablo 4. KTŞ ve HTŞ dolgu tabanı malzemesi karşılaştırması

\begin{tabular}{|l|l|l|}
\hline Deney & KTŞ & HTŞ \\
\hline 0.075 mm'den geçen, \% & $<50$ & - \\
\hline Likit Limit (LL), $\%$ & $<40$ & $<40$ \\
\hline Plastisite İndeksi (PI),\% & $<15$ & $<20$ \\
\hline Yaş (CBR) Esnek Üstyapılar, \% & $>10$ & $>15$ \\
\hline Uniformluk Katsayis1 & - & $>9$ \\
\hline Plaka Yükleme Testi (Mpa) & - & $\geq 30$ \\
\hline Standart Proctor (\%) & 100 & 100 \\
\hline
\end{tabular}

Yapım sırasında kullanılan malzemeyi ve oluşturulan tabakaları kontrol etmek amacıyla, her iki şartnamede de belirli aralıklarla yapılması gereken deneyler sıralanmıştır. Bu deneyler ve sayıları Tablo 5'de karşılaştırılmıştır. Tablolar incelendiğinde, KTŞ ve HTŞ'de kalite kontrol sıklıklarının aynı olduğu görülmüştür. KTŞ’ye göre yapılacak dolguların sıkışma kontrolünde daha fazla deney yapılması gerekmektedir. HTŞ'ye göre yapılacak dolgularda ise zemin taşıma gücü deneyi fazladır.

Tablo 5. KTŞ ve HTŞ kalite kontrol deney sıklıkları karşılaştırması

\begin{tabular}{|c|c|c|}
\hline Deney & KTŞ & HTŞ \\
\hline $\begin{array}{l}\text { Likit Limit-Plastik Limit } \\
\text { TS 1900, AASHTO T-89- } \\
90\end{array}$ & $\begin{array}{l}\text { Her } 1000 \mathrm{~m}^{3} \text { de ve her } \\
\text { farklı dolgu malzemesinde } \\
\text { bir deney }\end{array}$ & $\begin{array}{l}\text { Her } 1000 \mathrm{~m}^{3} \text { de ve her farklı dolgu } \\
\text { malzemesinde bir deney }\end{array}$ \\
\hline Doğal Su İçeriği, TS 1900 & $\begin{array}{l}\text { Her } 1000 \mathrm{~m}^{3} \text { de ve her } \\
\text { farklı dolgu malzemesinde } \\
\text { bir deney }\end{array}$ & $\begin{array}{l}\text { Her } 1000 \mathrm{~m}^{3} \text { 'de ve her farklı dolgu } \\
\text { malzemesinde bir deney }\end{array}$ \\
\hline 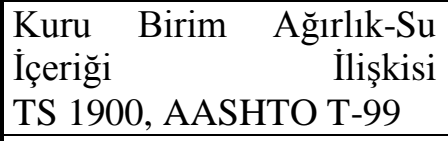 & \begin{tabular}{|l|} 
Her farklı malzeme sinıfi \\
için bir deney. \\
Her $1000 \mathrm{~m}^{2}$ de bir deney \\
\end{tabular} & $\begin{array}{l}\text { Her farklı malzeme sınıfı için bir } \\
\text { deney. } \\
\text { Her } 1000 \mathrm{~m}^{2} \text { de bir deney }\end{array}$ \\
\hline $\begin{array}{l}\text { Yaş CBR \%, TS 1900, } \\
\text { AASHTO T-193 }\end{array}$ & $\begin{array}{l}\text { Her farklı malzeme sınıfi } \\
\text { için bir deney }\end{array}$ & $\begin{array}{l}\text { Her farklı malzeme sınıfı için bir } \\
\text { deney }\end{array}$ \\
\hline $\begin{array}{l}\text { Nükleer Metod, AASHTO } \\
\text { T-238, } 239\end{array}$ & $\begin{array}{l}\text { Her Tabakada } 1000 \mathrm{~m}^{2} \text {, de } \\
\text { bir deney }\end{array}$ & 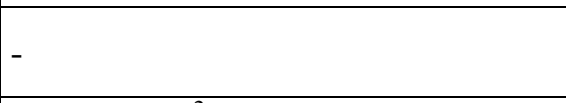 \\
\hline Plaka Yükleme Deneyi & - & Her $1000 \mathrm{~m}^{2}$ de bir deney \\
\hline
\end{tabular}

\subsection{Her İki Teknik Sartnamede Dolgu Issleri}

Karayolları Teknik Şartnamesinde;

Yol altyapısı bölümünde dolgu işlerine kısım 206 dolgular kısmında ve bölüm 300 sanat yapıları, köprüler ve tüneller bölümünde yer verilmiştir. KTŞ'de dolgu malzemesi içeriğinde aşağıdaki içeriğe sahip zeminlerin kullanılamayacağı belirtilmiştir: 
- Bitkisel toprak,

- Ağaç, çalı, kök ve benzeri organik maddeler,

- Kömür, kömür tozu dahil içten yanması söz konusu olan malzemeler,

- Bataklık veya suya doygun hale gelmiş killi ve marnlı zeminler,

- Enkaz vb. artık maddeler,

- İnsan ve çevre sağlığına zarar verecek oranda toksit madde içeren endüstriyel atıklar,

- Karl1, buzlu ve donmuş topraklar, suyla kolayca ufalanarak oturmalara neden olacak malzeme,

- Ağırlıkça \% 20' den fazla jips ve kaya tuzu gibi çözünebilen madde içeren topraklar.

KTŞ'de Tablo 6'daki dolgu malzemesinin sağlaması gereken özellikler belirtilmiştir.

Tablo 6. Dolgu malzemesi özellikleri

\begin{tabular}{|l|l|l|}
\hline DENEY & ŞARTNAME LIMITİ & DENEY STANDARDI \\
\hline Likit Limit (LL), $\%$ & $<60$ & TS 1900 AASHTO T - 89 \\
\hline Plastisite İndeksi (PI) $\%$ & $\leq 35$ & TS 1900 AASHTO T - 90 \\
\hline $\begin{array}{l}\text { Maks.kuru birim ağırlık } \\
\text { (Standart Proctor) }\end{array}$ & $\geq 1.45 \mathrm{tn} / \mathrm{m}^{3 *}$ & TS 1900 AASHTO T - 99 \\
\hline *PI $\leq 6$ ve CBR $>10$ olan doğal cüruflar ve tüflerde bu şart aranmaz \\
\hline
\end{tabular}

Don etkisi olan bölgelerde ise üstyapı tabanı, projesinde belirtilen derinliğe kadar, verilen malzeme özelliklerini taşıması gerekmektedir. Dolguların üstyapı tabanlarını oluşturan kısımlarında ise, esnek üstyapılar için $\mathrm{CBR}<8$ olan malzeme kullanılmamalı ve Tablo 7'de belirtilen özelliklere sahip malzeme ve inşaa sırasında buna uygun yapım metodları uygulanmalıdır.

Tablo 7. Dona etkisine hassas olmayan taban malzemesinin özellikleri

\begin{tabular}{|l|l|l|}
\hline DENEY & $\begin{array}{l}\text { ŞARTNAME } \\
\text { LIMITI }\end{array}$ & DENEY STANDARDI \\
\hline $0.075 \mathrm{~mm}$ Elekten geçen $\%$ & $\leq 12$ & TS 1900 AASHTO T -11 \\
\hline Likit Limit (LL), \% & $\leq 25$ & TS 1900 AASHTO T - 89 \\
\hline Plastisite İndeksi (PI), \% Agregada & $\leq 6$ & TS 1900 AASHTO T - 90 \\
\hline $\begin{array}{l}\text { Kaba A } \\
\text { Su Absorpsiyonu \% }\end{array}$ & $\leq 3$ & TS 3526 ASTM C - 127 \\
\hline
\end{tabular}

Koruyucu tabaka seçme malzemesi içeriğinde CBR şartname limitlerini sağlamak koşulu ile 0,075 mm' den geçen malzeme oranı $<20$ ise LL ve PI şartname limitleri ile birlikte, CBR şartname limitlerini sağlamak koşulu ile PI $<10$ ise $0,075 \mathrm{~mm}$ ' den geçen malzeme oranı şartname limitleri değerlendirilmeye alınmadan koruyucu tabaka seçme malzemesi olarak kullanılabilir (Tablo 8).

Tablo 8. Koruyucu tabaka seçme malzeme özellikleri

\begin{tabular}{|l|l|l|}
\hline DENEY & $\begin{array}{l}\text { ŞARTNAME } \\
\text { LiMITİ }\end{array}$ & DENEY STANDARDI \\
\hline $0.075 \mathrm{~mm}$ Elekten geçen $\%$ & $\leq 50$ & TS 1900 AASHTO T - 11 \\
\hline Likit Limit (LL), $\%$ & $\leq 40$ & TS 1900 AASHTO T - 89 \\
\hline Plastisite İndeksi (PI), $\%$ & $\leq 15$ & TS 1900 AASHTO T - 90 \\
\hline Yaş (CBR) Esnek Üstyapilar, $\%$ & $>10$ & TS 1900 AASHTO T-193 \\
\hline
\end{tabular}

KTŞ'ye göre su ve basınç altında dağılan ayrışma eğilimli kayaçlar (marn, kiltaşı, şeyl vb.) mekanik olarak ayrıştırıldığında dolgu malzemesi özelliklerine uygun ise yüksekliği 5 m'ye kadar olan dolgularda kullanılabilir. Bu tür malzemelerin üstyapı tabanında kullanılıp kullanılmamasına ek olarak malzemelere laboratuvar incelemesi yapıldıktan sonra karar verilir. 
Yaş CBR deneyi sonucunda \%3 ve daha yüksek oranda şişme gözlenen malzemelerin dolguda ve üstyapı tabanında kullanılması zorunlu durumlarda, kullanım şartları; dolgu yüksekliği, üzerine gelecek tabakaların kalınlığı, yapım tekniği vb. konular incelenerek ve bu durum ilave araştırma raporu hazırlanarak karar verilecektir.

KTŞ’ye göre dolguların yapımına başlanmadan önce, taban zemini ağaç kesme, kök sökme ve temizleme işlerinde belirtildiği şekilde temizlenir ve bitkisel toprağı sıyrılmış zemin kesimi $20 \mathrm{~cm}$ derinlikte kabartılıp sıkıştırılır. Dolgu yapımının kış aylarına rastladığı zamanlarda, dolgunun oturacağı kesimde bulunan kar ve buz temizlenir, zeminde donma söz konusu ise, don etkisi ortadan kalkıncaya kadar dolgu yapımına ara verilir.

Dolguların inşa edileceği sahada zayıf zemin, bataklık kesimler varsa bu kesimler; zayıf zeminler Kısım 203'de belirtildiği şekilde hazırlanır.

\subsubsection{Zaylf zeminler}

KTŞ'de zayıf zeminler, Tablo 9'da belirtilen niteliklerin tümünü birden sağlayamayan bütün kazıdan çıkan malzemeler olarak belirtilmiştir.

Tablo 9. Uygun nitelikli kazı malzemesi

\begin{tabular}{|l|l|l|}
\hline DENEY & ŞARTNAME LIMITI & DENEY STANDARDI \\
\hline Likit Limit (LL),\% & $<60$ & TS 1900 AASHTO T - 89 \\
\hline Plastisite İndeksi (PI), $\%$ & $\leq 35$ & TS 1900 AASHTO T - 90 \\
\hline $\begin{array}{l}\text { Maks.kuru birim ağırlık } \\
\text { (Standart Proctor) }\end{array}$ & $\geq 1.45 \mathrm{tn} / \mathrm{m}^{3 *}$ & TS 1900 AASHTO T - 99 \\
\hline *PI $\leq 6$ ve CBR>10 olan doğal cüruflar ve tüflerde bu şart aranmaz \\
\hline
\end{tabular}

Zayıf zeminler projelendirme aşamasında projelendirilmesi sırasında yapılan araştırma çalışmalarına göre (sondaj, araştırma çukuru, yüzey jeolojisi) yol ve yol yapıları altında yer alacak zayıf zeminlerin aşağıdaki niteliklerinin yapım öncesi belirlenmesi gerekmektedir:

- Niteliği (CL, CH, OH, vb),

- Kalınlığ1,

- Zamana bağlı oturma özellikleri,

- Şişme potansiyeli.

Zayıf zemin tabakasının kazılıp atılamayacak kalınlıklarda olması (kazı stabilitesi, su altında çalışma zorluğu, uzun mesafelerde kübaj artışı) durumunda ileri iyileştirme yöntemleri projelendirilerek uygulanır.

KTŞ'ye göre, proje aşamasında yapılan araştırma çalışmaları sırasında tam olarak belirlenemeyen veya yol genişletmeleri sırasında, sığ kalınlıktaki alüvyon geçişlerinde, yeraltı su seviyesinin yüzeye yakın olduğu durumlarda veya yüzey göllenmeleri olan ova geçişlerinde, bitkisel örtü kazısı sırasında karşılaşılan zayıf zeminlerin özellikleri, kalınlıkları, kayma dayanım parametreleri sondaj yada araştırma çukurundan alınan örneklere laboratuvar deneyleri sonucunda belirlenir [9-10].

Zayıf tabiî zemin tabakası, tespit edilen alandan belirtilen derinlikte kazılarak kaldırılıp, kontrol mühendisi tarafından gösterilen yerlere taşınır ve diğer kazı malzemelerinden ayrı bir yerde depo edilip muhafaza edilir. KTŞ’ye göre, yeraltı suyunun yüzeye yakın olması durumunda yol tabanı için önerilen drenaj şiltesinin filtrasyon ve permabilite kriterlerini sağlaması gerekir. Filtrasyon kriteri; drenajı sağlanan zemin tanelerinin drenaj malzemesinin tıkamaması, permabilite kriteri; drenaj malzemesinin suyu geçirebilme özelliğinin olması manasına gelmektedir.

\subsubsection{Dolguların yapılmasında KTŞde uygulanacak genel kurallar}

KTŞ'ye göre, dolguların yapımında uyulması gereken bazı kurallar şunlardır:

- Dolgular; sıkışma, oturma ve reglajdan sonra bütün noktalarda projede belirtilen plan, profil ve en kesite uygun olarak ve dolgunun tüm genişliği boyunca yüzey suyunun rahatça drenajını sağlayacak enine eğimde inşa edilmelidir.

- Dolguların korunmasından, stabilitesinden, malzemenin hatalı olmasından, dolgunun yapım ve onarım tekniğine uygun olarak yapılmamasından ortaya çıkan her türlü zarar ve iyileştirme çalışmalarından yüklenici sorumludur.

- Bataklık olmamak şartı ile dolgu yapılacak sahada toplanmış su varsa, dolgu yapılmadan önce bu suyun drene edilerek uzaklaştırılmalıdır. 
- Yarma-dolgu geçişlerinde; dolgu tabakalarının yarma yüzeylerine yaslandığı yerlerde dişler açılarak dolgu ve yarma kesitlerinin uyumlu olarak birleşmesi sağlanmalıdır.

- Dolgunun mevcut bir yol üzerine yapılması halinde, dolgu yüksekliği $50 \mathrm{~cm}$ 'den az ise, yeni dolgu malzemesi ile mevcut tabakalar arasındaki kaynaşmayı sağlamak üzere yüzey $15 \mathrm{~cm}$ derinlikte sürülerek, kabartılacak, dolgu malzemesi cinsine göre tabaka kalınlığı seçilerek yeni tabakalar oluşturulmalıdır.

- Sanat yapılarının üzerine gelecek dolgu yapımına bu yapıların inşaasının tamamlanmasından itibaren, hava sıcaklığ $5^{\circ} \mathrm{C}$ üzerinde olan gün sayısı $21^{\prime} i$ geçmeden başlanılmamalıdır. Ancak yapının her bir elemanından alınan numulerin dayanımları istenilen şartları sağlıyor ise 21 gün bekleme şartı aranmaz.

- Sanat yapıları yaklaşım, üst, yan ve arka dolgularında kullanılacak malzeme; bitkisel toprak, organik madde, buz parçaları, \%0.2'den fazla klorür ve \%0.3'den fazla sülfit içermeyecek ve aşağıdaki Tablo 10'de belirtilen özellikleri sağlamalıdır [9-13].

Tablo 10. Sanat yapıları yaklaşım ve yan dolgularında kullanılacak malzeme

\begin{tabular}{|l|l|}
\hline Özellikler & Şartname Limiti \\
\hline Tane boyutu, mm & $\leq 75$ \\
\hline $0.075 \mathrm{~mm}$ elekten geçen malzeme, $\%$ & $\leq 15$ \\
\hline Likit limit değeri, \% & $\leq 30$ \\
\hline
\end{tabular}

KTŞ'de dolguların oluşturulmasında verilen kurallardan sonra dolgu tabakalarının oluşturulma esasları incelenmiştir. Yayma işleminin dolgunun tüm genişliği ve boyunca yapılacağı, yayılan bir tabakanın, sıkıştırılmamış kesimlerine kesinlikle malzeme boşaltılmayacağı belirtilmiştir. Bitmiş tabakanın, herhangi bir noktası ile tabakanın proje kotu arasında $\pm 40 \mathrm{~mm}$ fark kabul edilebilir hata limitidir.

\subsubsection{Hırvat teknik şartnamesinde dolgu işlerinde esaslar}

Hırvat Teknik Şartnamesinde dolgu işleri, temel zeminlerinin iyileştirilmesi, zayıf zeminlerin kaldırılması, dolguların yapılması ve ileri zemin iyileştirme metodlarının incelenmesi alt başlıklarında detaylandırılmıştır. HTŞ'de, temel zeminlerinin iyileştirilmesi, kohezyonlu zeminlerin optimum su muhtevasını ve Tablo 11'deki standard proctor limitlerini sağlayacak biçimde sıkıştırılmasını, kohezyonsuz zeminlerde de benzer teknik uygulanmasını, kaya zeminlerde ise $20 \mathrm{~cm}$ kalınlığında parçalanmış kaya malzemenin zemine bir tabaka yapılarak sıkıştırılabileceği belirtilmiştir. Sıkıştırmanın kalite kontrolünün, standard proctor ya da CBR tayiniyle, her 1000 $\mathrm{m}^{2}$ ’lik kesimler için yapılması gerektiği belirtilmiştir.

Tablo 11. HTŞ temel zemini değerlendirme kriterleri

\begin{tabular}{|l|l|l|}
\hline Malzeme Tipi & Standard Proctor \% & $\begin{array}{l}\text { ZeminTaşıma Gücü } \\
(\mathrm{Mpa})\end{array}$ \\
\hline $\begin{array}{l}\mathrm{C} \text { malzeme } \\
\text { 2m 'e kadar olan dolgular için }\end{array}$ & 97 & 20 \\
\hline $\begin{array}{l}\mathrm{C} \text { malzeme } \\
\text { sinıf den fazla olan dolgular için }\end{array}$ & 95 & 20 \\
\hline $\begin{array}{l}\text { A-B sinıf malzeme } \\
2 \mathrm{~m} \text { 'e kadar olan dolgular için }\end{array}$ & 100 & 25 \\
\hline $\begin{array}{l}\text { A-B sinıf malzeme } \\
\text { 2m 'den fazla olan dolgular için }\end{array}$ & 95 & 25 \\
\hline
\end{tabular}

HTŞ’ye göre açıklanan şartlar sağlanamadığı durumlarda, aşağıdaki yöntem ya da yöntemlerden biri kontrol mühendisinin onayıla uygulanmalıdır:

- Uygun drenaj sistemi ile yüzey ve yer altı sularının uzaklaştırılması,

- Zayıf zeminin kaldırılarak yerine uygun malzeme getirilmesi,

- Zemine kireç, çimento ve hidrolik bağlayıcı ekleyerek iyileştirme yapılması,

- Geotekstil veya geogrid kullanılarak zeminlerin iyileştirilmesi. 
HTŞ'de zayıf zeminlerin kaldırılması, verilen koşullar sağlanamadığı zaman zayıf zeminlerin daha iyi malzeme taşınarak sıkışıtırılması olarak tanımlanmıştır. Eğer çizimlerde herhangi bir şekilde belirtilmemiş ise; 50 metre içinde test alınarak şartname limitlerine uyduğu takdirde malzeme serimine ve dolguların tamamlanmasına devam edilir. Test kısımlarına ait bütün harcamaların ve malzemenin uygun olmaması durumunda kaldırılması yüklenicinin yükümlülüğünde olduğu da şartnamede ayrıca belirtilmektedir.

\section{Sonuçlar}

Her iki şartnamenin kazı işleri açısından ortak yönleri; güvenli çalışma ortamının sağlanarak inşaata başlanması, çalışmalar esnasında oluşabilecek bütün imalat hatalarından ve bunlara ilişkin harcamalardan, bozulan taşıma yollarından, atık malzemelerin çevre etkilerine uygun biçimde taşınıp depo edilmesinden yüklenicinin sorumlu olduğu hükümleridir. Şartnamelerde dolgularda sağlanması gereken koşulların test edilme aralıklarına bakılarak incelendiğinde, iki şartnamenin de aynı yüzey alanlarında ve kübajlarda dolguların kontrolünü istediği görülmektedir. Benzer şekilde dolguların sıkışma kontrolünde standard proctor deney limitleri ve optimum su muhtevası sapma değerleri benzerdir. Şartname genelinde KTŞ, kontrol deneylerini AASHTO standardlarına eş Türk standardları ile belirtmiştir. HTŞ'ye de Hırvat standardlarına referans verilmiştir. HTŞ, KTŞ ile kıyaslandığında, özellikle geotekstil, geogrid seçimi ve kullanımına ilişkin daha detaylı bilgiler içermektedir. Bu malzemelerin kullanım amacı ve kullanılması gereken noktalar ve kullanım amaçları, her iki şartnamede de benzer şekilde açıklanmıştır.

Teknik şartnameler, projede tamamlananacak imalatların gerçekleştirilebilmesini sağlayan bütün bilgileri içermesi gerekmektedir. Bu bağlamda, imalata ait işçilik, malzeme, ekipman ve kalite kontrol koşulları şartnamelerde eksiksiz olarak açıklanmalı, şarnamenin kendi içinde çelişki bulunmamalıdır. Ayrıca, işin ihale sürecinden başlanılarak teklif oluşturulurken teknik şartnamelerin gereksinimleri araştırılmalı, eksik görülen noktalar için önceden risk planlaması yapılmalıdır.

\section{Kaynaklar}

[1] "KGM, Karayolları Esnek Üstyapılar Projelendirme Rehberi”, Karayollar Genel Müdürlüğü Teknik Araştırma Dairesi Başkanlığı, Ankara (2000).

[2] İTÜ, Ulaştırma Ana Planı Stratejisi, İ.T.Ü. Ulaştırma UYG-Merkezi, İstanbul (2005).

[3] C.M., Croatian Bureau of Statistics, Statical Yearbook of the Rep of Croatia, p. 355, Zagreb, (2012).

[4] Dündar G., Esnek Üstyapı Ttasarım Yöntemlerinin Karşılaştırılması, Yüksek Lisans Tezi, İstanbul Teknik Üniversitesi, İstanbul (1998).

[5] Küpçü E., Esnek Üstyapıların Projelendirilmesinde AASHO 1972 ve ASHO 1986 Yöntemlerinin Karşılaştırılması, Yüksek Lisans Tezi, İstanbul Teknik Üniversitesi, İstanbul, (1994).

[6] Avcı S., Esnek Üstyapı Tasarım Yöntemlerinden ASSHTO 2002 ile ASSHTO 1993 Yönteminin Karşılaştırılması, Yüksek Lisans Tezi, İstanbul Teknik Üniversitesi, İstanbul, (2006).

[7] KGM, Karayolları Teknik Şartnamesi, Ankara, (2006).

[8] IGH, General Technical Requirements, Institut Graðevinarstva Hrvatske, Zagreb (2001).

[9] McCarthy D. Es. of Soil Mechanics and Found.:Basic Geotechnic Pretince Hall (2006)

[10] AASHTO, Standart Specifications for Transportation Materials and Methods of Sampling and Testing, $12^{\text {th }}$ EdWashington D.C, (1978),

[11] Demirdağ M. N., Öztürk Z. 'Examination of the ratio of corrugation maintenance cost in superstructure maintenance cost in slab track superstructures', 'El-Cezeri Journal of Science and Engineering', 2017, Vol 4, No 3, 509-517, (2017).

[12] Öztürk O., Öztürk. Z., 'Investigation of the environmental effects of Ro-Ro Port on Sample Zone', El-Cezeri Journal of Science and EngineeringVol 5, No 1, 80-9, (2018)

[13] Erbaş F. E., Öztürk Z. 'Investigation of Transition Zones Between Bridge and Balastless Track for Light Rail Transit Systems with a Case Study', El-Cezeri Journal of Science and Engineering, Vol 5, No 1, 126-135, (2018). 